\title{
Evaluation of Sustainability Reporting Practices in Turkey
}

\author{
Dursun Ali Yaz \\ Suadiye Consultant of Finance and Tax Ltd., Turkey \\ Burcu Demirel Utku \\ Akdeniz University, Antalya, Turkey
}

\begin{abstract}
The purpose of the present study is to determine the reflection of sustainability reporting (SR), which gained momentum considerably during the recent years, on the organizations that are active in Turkey. Turkish businesses that carried out SR during January 1, 2005 and June 1, 2015 were included in the study. Altogether, 186 sustainability reports containing 6,240 pages of a total of 80 businesses were examined. Data obtained from these reports were classified into various categories. According to the results, it was determined that $84 \%$ of the reporting businesses reported according to Global Reporting Initiative (GRI) principles and preferred G3 framework (40\%); and the maximum number of reporting was published in 2014. The present study is the first research article including all businesses making SR in Turkey with all details.
\end{abstract}

Keywords: sustainability reporting (SR), non-financial disclosure, Global Reporting Initiative (GRI), Turkey

\section{Introduction}

The impact of business world on our behavior and habits has reached to an incontrovertible level. Because the essence of everything we use is soil and absolutely manufactured by an economic organization and submit to human use by the support of the peripheral services, such as shipping, trade, salesman, and delivery.

Therefore, companies are at the forefront of "sustainability" activities which aim to prevent blunting and even destruction of capabilities of the Earth that nurtures human and humanity. Therefore, the business world has quite challenging responsibilities as a part of society. Societies, now being aware of this case, hold not only the profitable, but also those contribute to sustainability of workers, customers, suppliers, their nation, and the Earth in high esteem.

Because of the fact that traditionally financial statements which became widespread with the Industrial Revolution do not wholly reflect the performance of companies of today, sustainability reporting stands out as a new "benchmark". Defined as the ability to meet the needs of the present without compromising the ability of future generations to meet their own needs, sustainability has become a new paradigm of economic development and a business model of global companies as a result of the improvement of reporting and auditing standards underpinned by a strong scientific framework. The objective of this work is to define when and how Turkish companies began "sustainability reporting", how much progress they made, the distance they covered in terms of this aspect, and where are they now. Base on the fact that "where there is nothing there is reporting", so in this report, we will take a closer look at the reflections of universal principles of sustainability on the economy of Turkey.

Dursun Ali Yaz, CPA, Suadiye Consultant of Finance and Tax Ltd.. Email: aliyaz@suadiyedenetim.com.tr.

Burcu Demirel Utku, associate professor, Faculty of Economics and Administrative Sciences, Akdeniz University. 


\section{Sustainability Reporting (SR)}

Ioana-Maria and Adriana (2012, p. 916) have stated the following opinion about the reasons of the occurrence of sustainable reporting in their studies conducted in 2012:

In a world dominated by global challenges, in the form of globalization, population growth, climate change, resource scarcity, recognition and response to sustainability issues is trivial for the corporate environment. Stakeholders influence on sustainability reporting is understated by organizations, which focus their disclosure on customers, employees, suppliers, activists, governments, community. The engagement with stakeholders is indeed increasing in importance as companies choose to disclose information on the matter.

Prospering of people economically makes them to become more sensitive and interested in their environment that they live in. When viewed from this perspective, environmentally sensitive moves of today's corporations affect favorably both their existing customers and potential customers (Markley \& Davis, 2007).

We can encounter numerous definitions made about the sustainability in literature. However, the well-accepted one among these definitions is the definition by World Commission on Environment and Development (WCED, 1987): "meeting the necessities of today's generations without sacrificing the ability to meet the necessities of the future generations". The environment concept can be shown as the first factor for the occurrence of sustainability. However, it covered economic, environmental, and social factors as well subsequently. We have left behind the times when financial statements were seen as the single criteria in the assessment of a company. Now, all shareholders of companies are interested in the economic, environmental, and social (governance) effects of the activities of a company. This perception change and demands have caused the sustainability reports to gain momentum (Akarçay, 2014). The Global Reporting Initiative's (GRI, 2011) Sustainability Reporting Guidelines defined SR as: “... the practice of measuring, disclosing, and being accountable to internal and external stakeholders for organizational performance towards the goal of sustainable development" (p. 3). SR is a broad term considered synonymous with others used to describe reporting on economic, environmental, and social impacts (e.g., triple bottom line, corporate responsibility reporting, etc.) (GRI, 2011).

The GRI has stated the benefits of SR in their draft called The Benefits of Sustainable Reporting:

... Widespread sustainability reporting practices, creating transparency, can help markets function more efficiently and indicate the health of the economy; and help drive progress by all organizations towards a smart, sustainable and inclusive growth. Organizations can use reporting to inform their risk analysis strategies and boost their business. A growing number of companies see sustainability reporting as a means to drive greater innovation through their businesses and products to create a competitive advantage in the market. Governments, businesses and stakeholders all directly benefit from it, and the positive impact on social, environmental and human rights issues is evident. (GRI, 2012, p. 1)

Dhaliwal, Radhakrishnan, Tsang, and Yang (2012) obtained striking results in their studies conducted on sustainability in 2012: “... Review of more than 7,000 sustainability reports from around the globe, researchers found that sustainability disclosures are being used to help analysts determine firm values and that sustainability disclosures may reduce forecast inaccuracy by roughly 10\%” (p. 724).

Now, thousands of international companies conduct studies in sustainability area, report them annually, and become the player of a disparate league by receiving assurance of independent inspection companies. Especially in the performance analyses of public companies, sustainability reports got ahead of even the financial analysts as a benchmark because the traditional financial statements do not reflect the entire picture. There is a critical increase in the number of sustainable reports in the world in general. Many of the world's largest companies now report on 
sustainability. For instance, as $20 \%$ of "Standard and Poor's 500" businesses issued sustainability reports in 2011, this ratio increased by 53\% in 2012 and by 72\% in 2013 (Boerner, 2014). In a recent study, KPMG (2011) found that $95 \%$ of the biggest 250 companies in the world reported on these issues and initiatives in some fashion (Searcy \& Buslovich, 2014). Multinational companies carry their organizational responsibility applications to their local networks as well. Thus, they contribute to the formation of a social liability culture in other shareholders who are related with these companies (Istanbul Stock Exchange [BIST], 2014a).

When the above given data are scrutinized, we can state that SR has turned into a global standard and started to have a wide usage area in the 21 st century business world (EY, 2013). As Hąbek (2014, p. 1740) indicated in his study, “... From year to year the number of reporting enterprises are growing. The European Union is the most active region in the world in terms of sustainability reporting". According to GRI (2015) statistics, the prepared table reveals the organization regions of sustainability reports. Romero, Lin, Jeffers, and DeGaetano (2014) mentioned the studies of the EU and United States on sustainability matter in their studies in the following way:

... The European Union proposed what is known as the "Europe 2020 Strategy" (European Commission, 2010), a new model of business based on sustainable growth. In the United States, the Sustainability Accounting Standards Board (SASB) was developed and incorporated in 2011. This not-for profit organization is engaged in the development of a framework and standards for use by publicly listed corporations to benefit investors and the public. (Romero et al., 2014, p. 69)

In Table 1, the continental distribution of sustainability report was given. A majority of the sustainability reports based on the date of the study are published in the European continent.

Table 1

Organization Regions of Sustainability Reports

\begin{tabular}{lrr}
\hline Organization region & \multicolumn{2}{c}{$\%$} \\
\hline Africa & 1,829 & 7 \\
Asia & 5,593 & 22 \\
Europe & 9,933 & 40 \\
Latin America \& the Caribbean & 3,100 & 12 \\
North America & 3,420 & 14 \\
Oceania & 1,125 & 5 \\
Total & 25,000 & 100 \\
\hline
\end{tabular}

Note. Table data have been gathered and organized from http://database.globalreporting.org/search.

There are various reporting frames accepted globally for clear, lucid, and transparent sustainable reporting by companies. These reporting frames prominent globally are G4 that was presented by GRI, Communication on Progress (COP, prepared as per United Nations Global Compact (UNGC)), Integrated Reporting (IR, prepared by International Integrated Reporting Council (IIRC)), and Carbon Disclosure Project (CDP) Reports (BIST, 2014b) prepared in the framework of CDP. According to KPMG (2008, p. 35):

One of the most important standards setters for reporting on sustainability is the Global Reporting Initiative (GRI), which was created in 1997 by the Boston-based nonprofit Ceres and the Tellus Institute, with the purpose of developing global standards. For years, the GRI database has been experiencing a constant increase in the number of countries and companies reporting on their sustainability initiatives.

According to EY (2013, p. 4), "The GRI Guidelines have been designed to harmonize with other prominent sustainability standards, including the OECD Guidelines for Multinational Organizations, ISO 26000 and the UN Global Compact". 
In EY's (2013) study called Value of Sustainability Reporting conducted in collaboration with the Boston College Center, GRI's short history has been mentioned:

... The Global Reporting Initiative was founded at the end of the 1990s. Only a few dozen companies filed reports with the GRI in its first few years, but with the environmental sustainability movement at its core, it quickly gathered momentum. By the mid-2000s, hundreds of companies were voluntarily adopting the GRI framework and producing sustainability reports. In January 2011, the GRI began collecting GRI-referenced and non-GRI-referenced reports. Today, thousands of companies, from all over the globe, are publishing sustainability reports. (EY, 2013, p. 5)

\section{SR in Turkey}

The history of SR is quite short in this country. Initially, 10 years ago, a sustainability report was published by a Turkish business and the number of our businesses following it has reached hundreds today. Turkish businesses of various sizes from various sectors report their sustainability reports that are prepared pursuant to the frame of especially GRI reporting. Kurumsal Sürdürülebilirlik (www.kurumsalsurdurulebilirlik.com), which is one of the leading platforms in this matter, is a communication platform which includes sustainable applications realized in Turkey and it is materialized as per GRI Regional Data Partnership Agreement entered into between GRI (www.kurumsalsurdurulebilirlik.com). We also benefited from the database of Kurumsal Sürdürülebilirlik (2015) in addition to sustainability disclosure database (GRI) for obtaining data used in our study.

We can show the Sustainability Index that started to be estimated with 15 Turkish businesses in BIST on November 4, 2014 as the most important step taken about the SR in Turkey. The purpose of BIST Sustainability Index has been defined as follows in BIST website:

... Forming an index as to include corporations which are traded at Istanbul Stock Exchange and whose organizational sustainability performances are at the top level is the improvement of understanding, knowledge and practices on sustainability matter among companies in Turkey and specifically in Istanbul Stock Exchange. (BIST, 2014b)

This index is considered as a crucial tool for the investors to distinguish readily the companies which developed sustainability and organizational social responsibility principles and to enable these companies to invest in these companies because SR in public companies has become an element sought by especially global investors.

In the work of BIST issued in 2014 and called Guide on Sustainability for Corporations, abstract development and significance of sustainability indexes have been mentioned. Since November 2014:

... The past of sustainability indexes goes back to the 1990s which include BIST sustainability index as well. On the other hand, the first sustainability indexes considered as a global sustainability indicator by financial markets and investors were established by Dow Jones and FTSE in 1999 and 2001 respectively. South Africa (2004) and Brasil (2005) had started to estimate sustainability index before many developed markets and lead the other developing markets. Since 2008, sustainability indexes started to be estimated in the developing countries including China, Indonesia, India, Hong Kong, Korea, Mexico and Egypt. (BIST, 2014a, p. 36)

Again, another tangible step taken on this matter for this country is the establishment of the sustainability platform as stated by BIST (2014a, p. 46):

... The "Sustainability Platform" was established in 2013 at the leadership of Istanbul Stock Exchange in order to exchange ideas in the matter of materializing the studies in sustainability field in this country as result oriented and effectively, and to create a sharing network to enable discussion of common steps to be taken in the sustainability matter. 
Public state and marketing values of Turkish firms which issue SR are shown in Table 2 below.

Table 2

Public State of SR Issued Companies (Turkey)

\begin{tabular}{ll}
\hline By state of being publicly traded (as of June 1,2015) & \\
\hline Number of companies open to the public & 539 \\
Number of public companies that declared sustainability report & 32 \\
Rate of number of companies that declared sustainability report & $6 \%$ \\
Market value of public companies & $620,833,208,000 \mathrm{TL}$ \\
Market value of companies that declared report & $332,855,052,400 \mathrm{TL}$ \\
Rate of the market value of companies that declared report & $53.6 \%$ \\
\hline
\end{tabular}

We completed this research on June 1, 2015, and as of that date, the rate of public companies that declared sustainability report seems low. But the total market value (not MCAP) of public companies that declared report is 332 billion liras and the rate of this amount to the total market value of BIST companies is more than half. In other words, the assets size of companies that declare sustainability report is quite big.

\section{Objective of the Study}

The present study aims to measure the reflections of SR, which is a product of the concept of "sustainable progress" that succeeded in politics and business world at the global level especially during the recent years, in Turkish business world. Conducting studies, preparing reports, and subjecting these to external auditing has been left to the initiative of the companies completely in Turkey. Sustainability reports prepared by institutions and organizations that are established in Turkey and shared by public form the most fundamental resource of this study. In order to access these reports, Kurumsal Sürdürülebilirlik (www.kurumsalsurdurulebilirlik.com) database, notably sustainability disclosure database (GRI), and web pages of the businesses have been benefited.

\section{Constraints of the Study}

The greatest constraint influencing the results of this study is flexibility or independence at the stage of preparation of sustainability reports in Turkey because, in addition to non-uniform information in the reports, measurement and unit values that are different than each other and different formats have made both data collection and classification of these data difficult. Another constraint is that $61 \%$ of the reporting companies prefer the annual period, and the remaining part issue biennial or three-year reports. This situation has led to some inconveniences for comparability.

Sustainability reports of "holding companies" constitute another constraint, because the leading holding companies in our country state consolidated figures in their reports. But the better part of these stated figures derives from its subsidiaries. We tried to avoid any repetition of these figures at maximum. Finally, industrial companies in particular do not recognize common criteria regarding the negative impact on environment and do not state their budget allocated for social activities; most importantly, lacking monetary equivalent of returns of sustainability operations is the biggest shortfall of the sustainability reports.

\section{Research Findings}

In the scope of the study purpose and constraints, sustainability reports issued by Turkish businesses have been scrutinized as to include the types, application levels, issue years, sectors, business sizes, report types, city-term, and other contextual details, and they are presented in Table 3. 
Table 3

Distribution of SR in Turkey on Yearly Basis and Based on Reporting Types and Application Levels

\begin{tabular}{|c|c|c|c|c|c|c|c|c|c|c|c|c|c|c|c|c|}
\hline Appl. levels & 2005 & 2006 & 2007 & 2008 & 2009 & 2010 & 2011 & 2012 & 2013 & 2014 & 2015 & $\mathrm{~T}^{*}(N)$ & $\%$ & Appl. levels & $\mathrm{EA}(N)$ & $\operatorname{IAR}(N)$ \\
\hline GRI G2 ${ }^{* *}$ & 1 & 1 & 1 & & & & & & & & & 3 & 2 & GRI G2 & & \\
\hline GRI G3 A & & & & & & & 1 & 1 & 1 & 1 & & 4 & 2 & GRI G3 A & & \\
\hline GRI G3 B & & & & & & 1 & 3 & 5 & 2 & 3 & & 14 & 8 & GRI G3 B & & \\
\hline GRI G3 C & & & & 2 & 2 & 9 & 3 & 7 & 6 & 2 & & 31 & 17 & GRI G3 C & & \\
\hline GRI G3 $\mathrm{A}^{+}$ & & & & & & & 1 & & & 1 & & 2 & 1 & GRI G3 $\mathrm{A}^{+}$ & 2 & \\
\hline GRI G3 $\mathrm{B}^{+}$ & & & & & & & 1 & 1 & 1 & 1 & & 4 & 2 & GRI G3 $\mathrm{B}^{+}$ & 4 & \\
\hline GRI G3 $\mathrm{C}^{+}$ & & & & & & & 2 & & & & & 2 & 1 & GRI G3 C $\mathrm{C}^{+}$ & 2 & \\
\hline $\begin{array}{l}\text { GRI G3 } \\
\text { undeclared }\end{array}$ & & & 1 & 3 & 1 & & 5 & 4 & 1 & 1 & & 16 & 9 & $\begin{array}{l}\text { GRI G3 } \\
\text { undeclared }\end{array}$ & & \\
\hline GRI G3.1 A & & & & & & & & & 3 & 4 & & 7 & 4 & GRI G3.1 A & & 3 \\
\hline GRI G3.1 B & & & & & & & 2 & 2 & 5 & 10 & & 19 & 10 & GRI G3.1 B & & - \\
\hline GRI G3.1 C & & & & & & & 3 & 1 & 3 & 4 & 1 & 12 & 6 & GRI G3.1 C & & 2 \\
\hline GRI G3.1 A ${ }^{+}$ & & & & & & & 1 & & 5 & 5 & & 11 & 6 & GRI G3.1 A $\mathrm{A}^{+}$ & 11 & 2 \\
\hline GRI G3.1 B & & & & & & & 2 & & & & & 2 & 1 & GRI G3.1 B & 2 & 5 \\
\hline GRI G3.1 $\mathrm{C}^{+}$ & & & & & & & 1 & & 1 & & & 2 & 1 & GRI G3.1 C $\mathrm{C}^{+}$ & 2 & - \\
\hline GRI G4 core & & & & & & & & & & 10 & 2 & 12 & 6 & GRI G4 core & 5 & 1 \\
\hline $\begin{array}{l}\text { GRI G4 } \\
\text { comprehen. }\end{array}$ & & & & & & & & & & 1 & 1 & 2 & 1 & $\begin{array}{l}\text { GRI G4 } \\
\text { comprehen. }\end{array}$ & 1 & 1 \\
\hline $\begin{array}{l}\text { GRI G4 } \\
\text { undeclared }\end{array}$ & & & & & & & & & & 2 & & 2 & 1 & $\begin{array}{l}\text { GRI G4 } \\
\text { undeclared }\end{array}$ & & \\
\hline $\begin{array}{l}\text { GRI } \\
\text { referenced }\end{array}$ & & & & & 1 & & 2 & 2 & 3 & 3 & & 11 & 6 & $\begin{array}{l}\text { GRI } \\
\text { referenced }\end{array}$ & & \\
\hline Non-GRI ${ }^{* * *}$ & & & & 2 & & 6 & 9 & 6 & 5 & 2 & & 30 & 16 & Non-GRI & 2 & 1 \\
\hline $\operatorname{Total}(N)^{* * * *}$ & 1 & 1 & 2 & 7 & 4 & 16 & 36 & 29 & 36 & 50 & 4 & 186 & 100 & Total $(N)$ & 31 & 15 \\
\hline$\%$ & 0.5 & 0.5 & 1 & 4 & 2 & 9 & 19 & 16 & 19 & 27 & 2 & 100 & & $\%$ & 17 & 8 \\
\hline
\end{tabular}

Notes. Table data have been obtained and arranged from http://database.globalreporting.org/search. *: Total: General level based on application levels; ${ }^{* *}$ : Content index only; ${ }^{* * *}$ : UNGC Progress Report, CSR Report, Progress Report, etc.; ${ }^{* * * *}$ : General sum based on years. EA: External assurance; IAR: Internationally awarded for reports.

The most known organization determining guidance for SR is the GRI, an international pioneer in SR with many stakeholders. The first version of the guidelines was launched in 2000. In 2002, the guidelines were revised and GRI launched the second generation of guidelines, the G2. The third generation of guidelines, the G3, was launched in 2006, then GRI published the G3.1, and finally, it published the G4 in 2013. The biggest innovation of the G4 is that it abolished the previous application levels. Reports that will be published as of December 31, 2015 have to comply with the guidelines of G4, so Table 3 is going to change in the forthcoming years.

Table 3 contains considerable details and has the most comprehensive content of the present study. When the data in this table are scrutinized; of the 186 reports comprising this sample, the distribution of the declared GRI application levels is as follows: 11 declared level A, 13 declared $\mathrm{A}^{+}, 33$ declared $\mathrm{B}$, six declared $\mathrm{B}^{+}$, 43 declared $\mathrm{C}$, four declared $\mathrm{C}^{+}, 18$ were undeclared but reported based on the GRI guidelines, 12 declared core (G4 levels), two declared comprehensive (G4 levels), and 30 declared non-GRI (UNGC Progress Report, CSR Report, Progress Report, etc.). Application level with the symbol "+" indicates that the report was externally assured by a third party. However, upon the issue of G4, both the application levels and "+" symbol have ended. The number of the businesses which get external auditing services is 31 . This is a $17 \%$ rate among 186 businesses and this illustrates that it is not accepted mostly because external auditing is not mandatory in SR. The effect on external sustainability reports in a study conducted by EY $(2013$, p. 17) is indicated as follows: 
... As more companies issue sustainability reports, analysts expect that public and investor demand for external assurance of sustainability reports will grow. Independent assurance of sustainability disclosures can help make a persuasive case for the reporter's seriousness and reliability. The GRI encourages external assurance, and there is strong evidence that investing in assurance is a wise decision since it enhances the credibility surrounding positive disclosures.

According to the results, $84 \%$ of businesses making SR do this in accordance with GRI principles although their application levels are different, while $16 \%$ of businesses report pursuant to various principles including UNGC Progress Report, CSR Report, Progress Report, etc.. The mostly preferred GRI application level by businesses making sustainability reports in Turkey is GRI G3 C.

Finally, the number of internationally awarded businesses for their issued sustainability reports is shown in the last column in Table 3. According to the results, 15 (8\%) of reporting businesses have won important awards in this matter. We think that these awards are very important for encouraging this reporting which has been developing in Turkey.

When Table 3 is viewed based on years, it is clear that SR in Turkey continued at a quite low level during the years of 2005-2010. Starting from 2010, as parallel to the increase globally, the number of businesses making SR has increased immensely. Especially, the increase in 2014 is remarkable. The reason for the low numbers in 2015 is that the businesses have not yet issued their related reports.

Table 4

SR Distribution Based on Reporting (Issue) Years

\begin{tabular}{|c|c|c|c|c|}
\hline \multirow{2}{*}{ Year } & \multicolumn{2}{|c|}{ SR number in Turkey } & \multicolumn{2}{|c|}{ SR number in the world } \\
\hline & $N$ & $\%$ & $N$ & $\%$ \\
\hline 1999-2004 & - & - & 777 & 3 \\
\hline 2005 & 1 & 0.5 & 404 & 2 \\
\hline 2006 & 1 & 0.5 & 561 & 2 \\
\hline 2007 & 2 & 1 & 781 & 3 \\
\hline 2008 & 7 & 4 & 1,242 & 5 \\
\hline 2009 & 4 & 2 & 1,671 & 7 \\
\hline 2010 & 16 & 9 & 2,223 & 9 \\
\hline 2011 & 36 & 19 & 3,395 & 13 \\
\hline 2012 & 29 & 16 & 3,979 & 16 \\
\hline 2013 & 36 & 19 & 4,436 & 18 \\
\hline 2014 & 50 & 27 & 4,800 & 19 \\
\hline 2015 & 4 & 2 & 731 & 3 \\
\hline Total & 186 & 100 & 25,000 & 100 \\
\hline
\end{tabular}

Note. Table data have been gathered and organized from http://database.globalreporting.org/search.

The developmental progress in this country in comparison to the world in SR based on years is shown in Table 4. In parallel to the progress in the world in the matter of SR, we can say that the awareness of our businesses on this matter based on years has increased and therefore the reporting number has risen. However, in this reporting which is quite novel for this country, it is clear that we are well below the global average. It is known that the first sustainability report samples in the world are 11 reports issued in GRI G1 report type in 1999. This increase in SR based on years has been realized in very critical ratios. 
Table 5

SR Distribution Based on Sectors

\begin{tabular}{|c|c|c|c|c|}
\hline \multirow{2}{*}{ Organization sector } & \multicolumn{2}{|c|}{ Turkey } & \multicolumn{2}{|c|}{ World } \\
\hline & $N$ & $\%$ & $N$ & $\%$ \\
\hline Agriculture & - & - & 274 & 1 \\
\hline Automotive & 10 & 5 & 540 & 2 \\
\hline Aviation & 3 & 1 & 422 & 2 \\
\hline Chemicals & 3 & 1 & 812 & 3 \\
\hline Commercial services & 3 & 1 & 509 & 2 \\
\hline Computer & 2 & 1 & 261 & 1 \\
\hline Conglomerates & 29 & 16 & 613 & 2 \\
\hline Construction & 4 & 2 & 732 & 3 \\
\hline Construction materials & 8 & 4 & 620 & 3 \\
\hline Consumer durables & 6 & 3 & 262 & 1 \\
\hline Energy & 14 & 8 & 1,713 & 7 \\
\hline Energy utilities & 4 & 2 & 1,269 & 5 \\
\hline Equipment & - & - & 509 & 2 \\
\hline Financial services & 20 & 11 & 3,253 & 13 \\
\hline Food and beverage products & 12 & 6 & 1,447 & 6 \\
\hline Forest and paper products & - & - & 439 & 2 \\
\hline Healthcare products & 16 & 9 & 581 & 2 \\
\hline Healthcare services & 2 & 1 & 280 & 1 \\
\hline Household and personal products & - & - & 322 & 1 \\
\hline Logistics & 6 & 3 & 547 & 2 \\
\hline Media & 1 & 1 & 296 & 1 \\
\hline Metals products & 5 & 3 & 527 & 2 \\
\hline Mining & - & - & 1,121 & 4 \\
\hline Non-profit/services & 1 & 1 & 590 & 2 \\
\hline Public agency & 2 & 1 & 447 & 2 \\
\hline Railroad & - & - & 175 & 1 \\
\hline Real estate & - & - & 685 & 3 \\
\hline Retailers & - & - & 681 & 3 \\
\hline Technology hardware & 1 & 1 & 737 & 3 \\
\hline Telecommunications & 10 & 5 & 839 & 3 \\
\hline Textiles and apparel & 16 & 9 & 277 & 1 \\
\hline Tobacco & - & - & 93 & 0 \\
\hline Tourism/leisure & - & - & 365 & 2 \\
\hline Toys & - & - & 13 & 0 \\
\hline Universities & 2 & 1 & 185 & 1 \\
\hline Waste management & - & - & 207 & 1 \\
\hline Waste utilities & - & - & 337 & 2 \\
\hline Others & 7 & 4 & 2,020 & 8 \\
\hline Total & 186 & 100 & 25,000 & 100 \\
\hline
\end{tabular}

Note. Table data have been gathered and organized from http://database.globalreporting.org/search.

Table 5 shows the distribution of SR in Turkey and the world based on sectors. It is clear that SR is made in almost all sectors when viewed globally. The sector where SR is made the most on a sector basis in Turkey is holding corporations with a $16 \%$ ratio, and financial services sector with a $13 \%$ ratio in the world. 
Table 6

SR Distribution Based on Organization Sizes

\begin{tabular}{lrrrrr}
\hline \multirow{2}{*}{ Organization size } & \multicolumn{2}{c}{ Turkey } & & \multicolumn{2}{c}{ World } \\
\cline { 2 - 3 } \cline { 5 - 6 } & \multicolumn{1}{c}{$N$} & \multicolumn{2}{c}{$N$} & & $\%$ \\
\hline Small- and medium-sized enterprises (SMEs) & 15 & 8 & 2,613 & 10 \\
Large enterprises & 148 & 80 & 16,578 & 67 \\
Multinational enterprises (MNEs) & 23 & 12 & 5,809 & 23 \\
Total & 186 & 100 & 25,000 & 100 \\
\hline
\end{tabular}

Note. Table data have been gathered and organized from http://database.globalreporting.org/search.

Table 6 shows the distribution of SR in Turkey and the world based on business sizes. According to Table 6, it is clear that large businesses make SR more than other businesses in both Turkey and the world. We think that some encouraging practices are needed for the rise of these ratios which are quite low especially in terms of SMEs.

Table 7

SR Distribution Based on Report Type

\begin{tabular}{|c|c|c|c|c|}
\hline \multirow{2}{*}{ Report type } & \multicolumn{2}{|c|}{ Turkey } & \multicolumn{2}{|c|}{ World } \\
\hline & $N$ & $\%$ & $N$ & $\%$ \\
\hline$\overline{\mathrm{G} 1}$ & - & & 307 & 1 \\
\hline $\mathrm{G} 2$ & 3 & 2 & 1,456 & 6 \\
\hline G3 & 73 & 40 & 10,938 & 44 \\
\hline G3.1 & 53 & 28 & 4,895 & 20 \\
\hline G4 & 16 & 8 & 1,527 & 6 \\
\hline GRI referenced & 11 & 6 & 1,870 & 7 \\
\hline Non-GRI & 30 & 16 & 4,007 & 16 \\
\hline Total & 186 & 100 & 25,000 & 100 \\
\hline
\end{tabular}

Note. Table data have been gathered and organized from http://database.globalreporting.org/search.

Table 7 shows the distribution of SR in Turkey and the world according to reporting types. According to Table 7, it is clear that the mostly used report type in both Turkey (40\%) and throughout the world (44\%) is GRI G3. Moreover, when Table 7 is viewed, the percentage of reports that are made in Turkey and throughout the world and we call UNGC Progress Report, CSR Report, Progress Report, etc. is only $16 \%$ in both Turkey and the world.

Table 8

Distribution of SR Doing Businesses According to Cities and Reporting Periods (Turkey)

\begin{tabular}{lrlrlr}
\hline By their location & $N$ & By periods of reporting & $N$ & By total number of pages & \multicolumn{1}{c}{$N$} \\
\hline Istanbul & 63 & Annual & 61 & Minimum & 13 \\
Ankara & 4 & Biennial & 18 & Maximum & 308 \\
Others & 13 & Triennial & 1 & The average & 74 \\
Total & 80 & Total & 80 & & \\
\hline
\end{tabular}

Note. : : Izmir 3, Bursa 3, Kocaeli 2, Adana 1, Hatay 1, Zonguldak 1, Çanakkale 1, and Kayseri 1.

There are 68 companies in Istanbul, Bursa, and Kocaeli (see Table 8); thus, Marmara region hosts $85 \%$ of companies that carry out sustainability activities and declare reports when compared to the total. We are not surprised to see that Marmara region is the leader of SR considering that the region provides more than half of tax revenues in the country. 
Even though there are certain standards determining the disposition of a report, that there is no penal repercussion for negligence of inspection and standards caused some companies to produce reports that are negatively flexible in terms of content, format, presentation, and data. That those companies were also not diligent enough in reporting by periods weakened our ability to make comparisons.

While the number of pages is not of major importance in qualitative aspects, it indicates that activities regarding sustainability bring about a lot of things to write about. More than half of the reports have illustrated parts and the average of the total number of pages seem reasonable.

Table 9

Distribution of SR Doing Businesses According to Various Factors (Turkey)

\begin{tabular}{|c|c|c|}
\hline \multicolumn{2}{|l|}{$\overline{\text { Factor }}$} & \multirow{2}{*}{$\begin{array}{l}N \\
\\
\end{array}$} \\
\hline $\begin{array}{l}\text { By average lifespan of } \\
\text { the companies }\end{array}$ & $\begin{array}{l}\text { As of the end of 2014, average lifespan of companies that declare } \\
\text { sustainability reports }\end{array}$ & \\
\hline \multirow{4}{*}{$\begin{array}{l}\text { By average annual } \\
\text { revenue and employees }\end{array}$} & Total annual revenue (could not reach the information of eight ones) & $4,419,365.133 \mathrm{TL}$ \\
\hline & Average annual revenue (could not reach the information of eight ones) & $55,242.065 \mathrm{TL}$ \\
\hline & Total number of employees (there is no information about five of them) & 390,092 \\
\hline & Average number of employees (there is no information about five of them) & 4,876 \\
\hline \multirow{2}{*}{ By state of labor union } & Unionized companies & 28 \\
\hline & Total union members (employees) & 146,556 \\
\hline \multirow{2}{*}{$\begin{array}{l}\text { By educational status of } \\
\text { employees }\end{array}$} & Companies that provide education & 52 \\
\hline & The average of educational hours & 29 \\
\hline \multirow{4}{*}{$\begin{array}{l}\text { Chamber of Industry and } \\
\text { the rankings of Fortune } \\
\text { (as of June } 1,2015 \text { ) }\end{array}$} & On Fortune list & 1 \\
\hline & Number of companies that are members of Istanbul Chamber of Industry & 23 \\
\hline & $\begin{array}{l}\text { TUSIAD (The Board of Directors of the Turkish Industry and Business } \\
\text { Association) }\end{array}$ & 33 \\
\hline & MUSİAD (Independent Industrialists' and Businessmen's Association) & 1 \\
\hline $\begin{array}{l}\text { By rewards for } \\
\text { sustainability activities }\end{array}$ & $\begin{array}{l}\text { Our businesses have been granted with a total of } 62 \text { awards for its } \\
\text { sustainability field in the national and international arena (six of them } \\
\text { received awards for sustainability report) }\end{array}$ & \\
\hline
\end{tabular}

Considering that the length of 12 years is the average lifespan of 300.000 active and 300.000 inactive companies, well-established companies pay more attention to sustainability.

According to Table 9, 390,092 is an important number when we look at the number of employees in companies that released sustainability reports. Even though the bigger part of society is not aware of the concept of sustainability, especially by establishments that have close relations with the public such as banks, major appliances companies, municipality, and universities handling this issue, it is possible to say that in people's daily lives, the positive changes brought by this sustainability concept are noticed.

Easing the life is the core of sustainability ethics. All principles are meant for that end. The concept of sustainability places great importance to the activities of unions which aim to alleviate concerns of employers and to protect acquired rights. One-third of companies that declare report are unionized and the rate of employees that are members of eight different unions to the total number of employees is $40 \%$.

The most essential sign of a company that has attained "corporate consciousness" level to produce a sustainability report is the importance it places on human resources. Indeed, when reports are examined, we are seeing companies allocate more and more resources to education and they are being more meticulous about reporting these activities which increases the overall quality and strengthens the sense of belonging of employees. 
Table 10

An Examination of Sustainability Reports in Terms of Ecological Footprint Results (Turkey)

\begin{tabular}{|c|c|c|}
\hline Factor & Distribution & $N$ \\
\hline \multirow{4}{*}{$\begin{array}{l}\text { By reduction amounts of } \mathrm{CO}_{2} \text { stated in } \\
\text { reports on greenhouse gas emission } \\
\left(\mathrm{CO}_{2}\right)\end{array}$} & Number of establishments that produce reports & 41 \\
\hline & Number of establishments that did not give disclosure & 39 \\
\hline & $\begin{array}{l}\text { Those reduced greenhouse gas emission }(3,801.785 \text { total amount } \\
\left.\text { of } \mathrm{CO}_{2} \text { reduced }\right)\end{array}$ & 31 \\
\hline & Those increased greenhouse gas emission & 10 \\
\hline \multirow{4}{*}{$\begin{array}{l}\text { Reduction amounts stated in reports on } \\
\text { electricity consumption (Kwh) }\end{array}$} & Number of establishments that produce reports & 50 \\
\hline & Number of establishments that did not give disclosure & 30 \\
\hline & $\begin{array}{l}\text { Those who reduced electricity consumption (the total amount of } \\
\text { electricity saved (Kwh): } 6,779,461.768 \text { ) }\end{array}$ & 38 \\
\hline & Those who increased electricity consumption & 12 \\
\hline \multirow{4}{*}{$\begin{array}{l}\text { Reduction amount stated in reports on } \\
\text { water consumption }\left(\mathrm{m}^{3}\right)\end{array}$} & Number of establishments that produce reports & 42 \\
\hline & Number of establishments that did not give disclosure & 38 \\
\hline & $\begin{array}{l}\text { Those who reduced electricity consumption (the total amount of } \\
\left.\text { water saved }\left(\mathrm{m}^{3}\right): 6,425.215\right)\end{array}$ & 33 \\
\hline & Those who increased electricity consumption & 9 \\
\hline \multirow{2}{*}{$\begin{array}{l}\text { By performance of afforestation } \\
\text { (Number) }\end{array}$} & Number of establishments that produce reports & 24 \\
\hline & Number of saplings planted & $2,834.978$ \\
\hline \multirow{2}{*}{ By performance of paper saving (by tons) } & Number of establishments that produce reports & 22 \\
\hline & The amount of paper saved (by tons) & 774,455 \\
\hline \multirow{2}{*}{ By performance of recycling (by tons) } & Number of establishments that produce reports & 42 \\
\hline & The amount of recycled parts (by tons) & $8,848.827$ \\
\hline \multirow{2}{*}{$\begin{array}{l}\text { By profitability rates of sustainability } \\
\text { activities (by Turkish lira) }\end{array}$} & Number of establishments that produce reports & 10 \\
\hline & The amount of recycled parts (by tons) & $107,202.400$ \\
\hline
\end{tabular}

Table 10 is prepared to determine the ecological footprints of companies which issue sustainability reports in Turkey. According to Table 10, information on carbon footprint, electricity consumption, water consumption, paper saving, recycling, and profitability rates of sustainability activities have been given.

Global Footprint Network (GFN) is an organization which achieved important studies especially on carbon footprint. In addition, the results of the study which this organization conducted in 2007 are quite interesting: "Aiming to improve the 'the science of sustainability', GFN introduced the concepts such as biocapacity and carbon footprint" (GFN, 2007).

According to World Wide Fund for Nature (WWF, 2012):

... GFN devised a method to measure how much earth and water is required to compensate ecological resources that are consumed by total population of Earth, continents and nations. This method is defined as "ecological footprint". According to their report of 2007, it takes 16 months for Earth to compensate for what humanity consumes in a year. This means, we need 1.3 Earths. In other worlds, we are using more than 1.3 Earth's worth of resources to sustain our lifestyles. Again, according to the statistics of this organization in 2003, the total biocapacity of Earth is 12 million global hectares and biocapacity per capita is 1.78 global hectares (when the population of 6.3 billion is taken into account). In 2003, ecological footprint of Earth is 2.23 global hectares. This number indicates that we exceeded the biocapacity level of Earth by $25 \%$. The data shows biocapaciy level of the UK per capita is 1.6 gha, her ecological footprint is 5.6 and in this case the UK requires 3.5 Planet Equivalents. Being a major country in terms of biocapacity, the biocapacity of the USA per capita is 4.7 gha and her ecological footprint is 9.6 gha. Thus, the USA needs 2.04 Planet Equivalents. The biocapacity of Africa in general is 1.3 gha, her ecological footprint is 1.1 . Therefore she needs 0.85 Planet Equivalents. Biocapacity of other countries has been calculated as well. We cannot predict how much more China will exceed her biocapacity with this development pace, but she has already exceeded 2.5 times. Russia has nearly depleted her enormous capacity. 
In the book called Letters to the Sustainable Future, the state of the EU and this country on this matter has been emphasized:

... European Union has pledged a 20\% reduction in greenhouse gases in 2020 in comparison to 1990, and declared that they will accept a 30\%-reduction in case of a global agreement. They request that this undertaking is adapted by the United Nations Charter Annex-1 countries, all OECD member countries, EU candidate countries and potential EU candidate countries in addition to all developed countries. As will be seen, Turkey, which is a Charter Annex-1 country, an OECD member and EU candidate, is among the countries that the EU requests that they take a binding target. (Yaz \& Çil, 2013, p. 256)

“... The biggest item on the foreign trade deficit of Turkey, energy import cost 39 billion American dollars in the first 8 months of 2012" (Enerji Time, 2012). Considering the increasing demand for energy, energy sector has to follow the principle of domestic or renewable energy production in order to secure the energy supply of Turkey. Sustainability reports show (see Table 10) that 38 of 50 establishments which disclosed the environmental impact of their activities reduced their electricity consumption, while 12 of them increased their consumption.

United Nations Development Programme (UNDP, 2006) has described the water problem of the world with the following statements simply in their Human Development Report issued in 2006:

... Water resources of over 1.1 billion people in the world are unhealthy, with bacteria or they are over their purchasing power. According to 2006 Human Development Report, the statement "not able to access clean water" is a polite way of saying extreme poverty. These people have to walk to the nearest clean water resource for miles every day in order to find a bucket of drinking water. Or they collect water from ravines, canals and creeks which are polluted with bacteria that could lead to illnesses even death. (UNDP, 2006, p. 2)

All companies, whether they attempt to benefit economically or not, must see this reality and care about water consumptions and not to pollute water resources with their waste.

According to Table 10, 24 companies carried out afforestation near their main locations or working sites so as to protect natural life and biodiversity. According to their latest reports, those companies planted almost 3 million saplings. A significant number of companies raised mass consciousness through introducing these activities as part of corporate project and secured the continuity of projects as well.

Banks, holding and companies that employ packaging intensively are especially conscious about paper saving. By saving 774,455 tons of paper (see Table 10), they saved 13 million trees.

We can observe in the reports that there is reluctance in terms of recycling data reporting. At first glance, it may be seen high relatively but it is insufficient in our opinion. The Brundtland Report emerged out of environmental concerns. Reporting the activities may be seen as a major burden to companies but disclosure about the processes which have a negative impact on environment is the measure of sincerity about sustainability. There is an important detection in Çil's (2014) study about the report of Brundtland:

... Various development needs of countries, prosperity desire of developing country people, injustice in income distribution including developed countries as well, unbelievable eagerness to consumption, ideological attitudes, political targets, and different understanding of determining and solving problems have revealed Brundtland Report's correctness once again to leave the sustainable development definition broad and vague, to extend over time and the suggestion of participation of everyone. (Çil, 2014, p. 1)

Usually, industrial companies create projects and publish their progress in the area of sustainability. The activities that they carry out have a high level of economic, environmental, and social impacts. That monetary gain from sustainability activities is presented in the report has encouraged other firms to give 
disclosure as well. For now, those who declared their monetary gains from sustainability activities on the basis of Turkish lira have been $15 \%$. Indeed, we can indicate the matter that we care the most among numerous benefits of sustainability reports in the following way: The contributions of a company to society through cultural, social, environmental, artistic, etc. activities will also contribute to its corporate memory. These measurements are useful in setting new targets through comparing the previous ones; thus, the company will improve itself each year. The company as a role model to sectoral companies and relevant organizations will create a butterfly effect.

Table 11

An Examination of Sustainability Reports in Terms of Social Projects (Turkey)

\begin{tabular}{ll}
\hline Social activity & $N$ \\
\hline $\begin{array}{l}\text { Number of establishments that produce reports (educational, health, cultural, agricultural, family, sportive, } \\
\text { husbandry, life, etc.) }\end{array}$ & 77 \\
\hline
\end{tabular}

The main goal of each company that prepares report is to disclose all positive and negative economic, social, and environmental impacts of their commercial activities transparently. Especially, financing companies that are in close connections with their clients and establishments that are sensitive to this case in terms of brand awareness place a great emphasis on creating social effects sections. Thus, social issues are widely presented in sustainability reports. From occupational health safety to numerous social projects as part of social responsibility, activities revealing the expectations of the public have been presented with narrative nature. Therefore, these social activities of 77 companies (as seen in Table 11) are worthy of being a matter of another research.

Table 12

An Examination of Sustainability Reports in Terms of Economic Projects (Turkey)

\begin{tabular}{|c|c|c|}
\hline Economic project & Distribution & $N$ \\
\hline $\begin{array}{l}\text { Economic } \\
\text { activities }\end{array}$ & $\begin{array}{l}\text { Number of establishments that produce reports (environmental and extension investments, } \\
\text { renewable energy, R\&D, innovations, foundations, and associations) }\end{array}$ & 73 \\
\hline \multirow{8}{*}{$\begin{array}{l}\text { By level of } \\
\text { imposing } \\
\text { regulation on } \\
\text { suppliers }\end{array}$} & Number of establishments that produce reports & 46 \\
\hline & Expected to & 5 \\
\hline & Voluntarily & 1 \\
\hline & On condition to comply & 10 \\
\hline & Prioritized & 12 \\
\hline & Being checked & 16 \\
\hline & Ending the business relationship & 4 \\
\hline & Signing contract & 4 \\
\hline
\end{tabular}

In Table 12, we took all expenditures, except the advertisement and marketing, of 73 companies into account which allocated financial resources for various activities as part of sustainability.

Reports that will be published as of December 31, 2015 have to comply with the guidelines of the G4. One of the most important changes the G4 brings is that companies have to give information about their suppliers. As regulations created by companies towards suppliers increase, these suppliers will impose similar regulations on their suppliers; thus, the principles of sustainability will bring about a "butterfly effect". The results above are taken from the latest reports. Therefore, we will see how the markets will react to the multiplier effect when companies begin reporting their suppliers in the forthcoming years. 


\section{Conclusion}

The present study is mainly a quantitative study comparing the state of Turkey in the matter of SR with the global averages and to reveal it. Here, the qualitative examination of the reports, which are subject to a quantitative examination, forms a foundation for future studies.

In the present study, sustainability reports were taken as the basis that were issued during the period from 2005, the first issue date, till the end of June 2015, and the interest and attention paid to the sustainability concept in Turkish business world were revealed by comparisons with the world in general. For this purpose, 12 comprehensive tables were prepared including interpretations and analyses.

The number of businesses, which declare their sustainability performances based on certain frameworks in both the world and Turkey, is increasing gradually. Some of these businesses include their studies on sustainability in their activity reports, and some of them inform their shareholders in their web pages under the name of sustainability. However, in addition to these, a majority of the businesses which are interested in sustainability declare their sustainability reports that are separate from their activity reports and are prepared based on certain frameworks.

It is observed that the sustainability understanding, which is headed by the pioneering groups of Turkey, has been taken into consideration day by day by SMEs as well. In conclusion, the momentum observed in developed countries seems to be caught up although the number of the issued reports in this country is low. It is encouraging to see that this paradigm change, which has been discussed and labored since becoming literature in 1987, has an increasing momentum. If Turkey, as a candidate country to become a member in the EU, is planning to carry its economy to among the first 10 economies in a healthy and steady way, sustainability should be the fundamental strategy of Turkish business world.

\section{References}

Akarçay, Ç. (2014). Sürdürülebilirlik Muhasebesi Standartlari Kurulu. Marmara University Öneri Journal, 11(42), 1-11.

BIST. (2014a). Şirketler İçin Sürdürülebilirlik Rehberi. BORSA Istanbul. Retrieved from http://www.borsaistanbul.com/data/kilavuzlar/surdurulebilirlik-rehberi.pdf

$\begin{array}{llllll}\text { BIST. } & \text { (2014b). } & \text { BIST } & \text { Sürdürülebilirlik } & \text { Endeksi. } & \text { Retrieved }\end{array}$ http://www.borsaistanbul.com/endeksler/bist-pay-endeksleri/surdurulebilirlik-endeksi

Boerner, H. (2014). Flash report: 72\% of S\&P 500 companies now publishing sustainability/responsibility reports. Retrieved from http:/ga-institute.com/Sustainability-Update/2014/06/03/flash-report-72-of-sp-500-companies-now-publishing-sustainability-r esponsibility-reports/

Çil, F. (2014). Brundtland vizyonunun devrimselliği. $\quad$ Retrieved from http://www.borsagundem.com/fatih-cil-yazar77/brundtland-vizyonunun-devrimselligi-635385y.htm

Dhaliwal, D. S., Radhakrishnan, S., Tsang, A., \& Yang, Y. G. (2012). Nonfinancial disclosure and analyst forecast accuracy: International evidence on corporate social responsibility disclosure. The Accounting Review, 87(3), 723-759.

Enerji Time. (2012). Türkiye'nin 8 aylı enerji ithalatı faturası 39 milyar doları aştı. Retrieved from http://enerjitime.com/index.php/turkiyenin-8-aylik-enerji-ithalati-faturasi-39-milyar-dolari-asti.html

European Commission. (2010). Europe 2020: A strategy for smart, sustainable and inclusive growth. Retrieved from http://ec.europa.eu/eu2020/pdf/COMPLET\%20EN\%20BARROSO\%20\%20\%20007\%20\%20Europe\%202020\%20-\%20EN $\% 20$ version.pdf

EY. (2013). Value of sustainability reporting: A study by EY and Boston College Center for corporate citizenship. Center for Corporate Citizenship \& Boston College and Carroll School of Management. Retrieved from http://www.ey.com/Publication/vwLUAssets/EY_-_Value_of_sustainability_reporting/\$FILE/EY-Value-of-Sustainability-Re porting.pdf 
GFN. (2007). Global footprint network 2007 annual report. Retrieved from http://www.footprintnetwork.org/images/uploads/2007_AnnualReport_Final.pdf

GRI. (2011). Sustainability reporting guidelines. Global Reporting Initiative. Retrieved from https://www.globalreporting.org/resourcelibrary/G3.1-Guidelines-Incl-Technical-Protocol.pdf

GRI. (2012). The benefits of sustainability reporting. Global Reporting Initiative. Retrieved from https://www.globalreporting.org/resourcelibrary/The-benefits-of-sustainability-reporting.pdf

GRI. (2015). Sustainability disclosure database. Retrieved from http://database.globalreporting.org/search

Hąbek, P. (2014). Evaluation of sustainability reporting practices in Poland. Quality \& Quantity, 48(3), 1739-1752.

Ioana-Maria, D., \& Adriana, T. T. (2012). The impact of the business and organizational size of a company along with GRI and CSR adoption on integrating sustainability reporting practices. Annals of the University of Oradea, Economic Science Series, 1(1), 916-920.

KPMG. (2008). International survey of corporate responsibility reporting. Retrieved from https://www.kpmg.com/EU/en/Documents/KPMG_International_survey_Corporate_responsibility_Survey_Reporting_2008. pdf

KPMG. (2011). International survey of corporate responsibility reporting. Retrieved from https://www.kpmg.com/PT/pt/IssuesAndInsights/Documents/corporate-responsibility2011.pdf

Kurumsal Sürdürülebilirlik. (2015). Retrieved from http://www.kurumsalsurdurulebilirlik.com/tr-tr/rapor-arama.aspx

Markley, M. J., \& Davis, L. (2007). Exploring future competitive advantage through sustainable supply chains. International Journal of Physical Distribution \& Logistics Management, 37(9), 763-774.

Romero, S., Lin, B. B., Jeffers, A. E., \& DeGaetano, L. A. (2014). An overview of sustainability reporting practices. The CPA Journal, 84(3), 68-71.

Searcy, C., \& Buslovich, R. (2014). Corporate perspectives on the development and use of sustainability reports. Journal of Business Ethics, 121(2), 149-169.

UNDP. (2006). Human development report $2006 . \quad$ Retrieved from http://www.tr.undp.org/content/turkey/tr/home/presscenter/news-from-new-horizons/2006/12/15/water-costs-the-most-for-po or.html

WCED. (1987). Report of the World Commission on Environment and Development: Our common future. Retrieved from $\mathrm{http}: / /$ www.un-documents.net/wced-ocf.htm

WWF. (2012). Türkiye'nin Ekolojik Ayak Izi Raporu. WWF RAPOR. Retrieved from http://www.footprintnetwork.org/images/article_uploads/Turkey_Ecological_Footprint_Report_Turkish.pdf

Yaz, D. A., \& Çi1, F. (2013). Sürdürülebilir Geleceğe Mektuplar. Istanbul: Suadiye Yayınları. 